\title{
ANTIBACTERIAL TRITERPENOIDS FROM THE BARKS AND LEAVES OF Lansium domesticum Corr cv. Kokossan (MELIACEAE)
}

\author{
T. Mayanti*, Y. P. Apriantini, S. Soidah, J. Sianturi, D. Darneti, E. Julaeha, D. Sumiarsa, \\ Nurlelasari, and R. Maharani'
}

\author{
Department of Chemistry, Faculty of Mathematics and Natural Sciences, \\ Padjadjaran University, Jatinangor 45363, Indonesia \\ ${ }^{*} E$-mail: t.mayanti@unpad.ac.id
}

\begin{abstract}
Three triterpenoid compounds, 8,14-secogammacera-7,14-dien-3,21-dione (1), 8,14-secogammacera-7en-14-hydroxy-3,21-dione (2) and 9,19-cyclolanost-24-en-3-one, 21,23 epoxy-21,22-dihydroxy (21R, 22S, 23S) (3) has been isolated from the barks and leaves of L. domesticum cv kokossan (Meliaceae). The chemical structures of compounds 1-3 were identified with spectroscopic data, including UV, IR, NMR and MS, and their spectra were compared with previously reported spectra data. Compound 1, 2 were evaluated for their antibacterial effects against Escherichia coli and Bacillus ereus. Compound $\mathbf{3}$ was evaluated for their antibacterial effects against Escherichia coli and Enterococcus feacalis. Compound $\mathbf{1}$ showed the inhibition zone values of 7.5 dan $8.0 \mathrm{~mm}$ at 500 and $1000 \mathrm{ppm}$ against Escherichia coli, whereas for Bacillus cereus it was inactive. Compound 2 showed the inhibition zone values of 8.0 dan $10.0 \mathrm{~mm}$ at concentrations of 500 and 1000 ppm against Escherichia coli, whereas for Bacillus cereus it was inactive. Compound $\mathbf{3}$ showed the inhibition zone values of $3.67 \mathrm{~mm}, 3.17 \mathrm{~mm}, 2.32 \mathrm{~mm}$ at concentrations of 10000, 5000 and $1000 \mathrm{ppm}$ respectively against Escherichia coli, whereas for Enterococcus feacalis it was inactive.
\end{abstract}

Keywords: Lansium domesticum, antibacterial, Escherichia coli, Enterococcus feacalis, Bacillus cereus

\begin{abstract}
ABSTRAK
Tiga senyawa triterpenoid, 8,14-sekogamasera-7,14-dien-3,21-dion (1), 8,14-sekogamasera-7-en-14hidroksi-3,21-dion (2) dan 9,19-siklolanost-24-en-3-on, 21,23 epoksi-21,22-dihidroksi $(21 R, 22 S, 23 S)(3)$ telah diisolasi dari kulit batang dan daun $L$. domesticum cv kokossan (Meliaceae). Struktur kimia senyawa 1-3 telah ditentukan melalui data spektroskopi UV, IR, NMR dan MS serta perbandingan dengan data spektroskopi laporan sebelumnya. Senyawa 1, 2 dievaluasi sifat antibakterinya terhadap Escherichia coli dan Bacillus cereus. Senyawa 3 dievaluasi sifat antibakterinya terhadap Escherichia coli dan Enterococcus feacalis. Senyawa 1 menunjukkan nilai zona hambat sebesar 7,5 dan $8,0 \mathrm{~mm}$ pada konsentrasi berturut-turut 500 dan 1000 ppm terhadap Escherichia coli dan tidak aktif terhadap Bacillus cereus. Senyawa 2 menunjukkan nilai zona hambat sebesar 8,0 dan 10,0 mm pada konsentrasi berturut-turut 500 dan 1000 ppm terhadap Escherichia coli dan tidak aktif terhadap Bacillus cereus. Senyawa 3 menunjukkan nilai zona hambat $3,67 \mathrm{~mm}, 3,17 \mathrm{~mm}, 2,32 \mathrm{~mm}$ pada konsentrasi berturut-turut 10000, 5000 dan 1000 ppm terhadap E. coli, tidak aktif terhadap E. feacalis.
\end{abstract}

Kata kunci: Lansium domesticum, antibakteri, Escherichia coli, Enterococcus feacalis, Bacillus cereus.

\section{INTRODUCTION}

Lansium domesticum Corr (Meliaceae) is a popular fruit in southern Asia. Kokossan is one of three cultivars of $L$. domesticum which are widely grown throughout Indonesia. Lansium has long been used in traditional medicine as a cure for diarrhea. Preliminary research on the study of the use of seed duku, L. domesticum, as diarrhea drug in vitro has been carried out by Loekitowati et al. (2000).
The results showed the ethanol extract, fraction of $n$-hexane, dichloro-methane, and ethyl acetate are active against bacteria that cause diarrhea in vitro namely E. coli, Salmonella typhi and Shigella flexneri. Five onoceranoid triterpenes from fruit peels of $L$. domesticum; $3 \beta$-hydroxyonocera-8(26),14-dien-21-dione;

$\alpha, \gamma$-onocera-dienedione; lansiolic acid; lansionic acid and lansioside $\mathrm{C}$ showed moderate activities against Candida albicans and Aspergillus niger, and low activities 
against Trichophyton mentagrophytes (Ragasa et al., 2006). Lansioside D isolated from the fruit peel of $L$. domesticum has remarkable activity against Staphylococcus aureus and Bacillus subtilis, and moderate activity against Escherichia coli (Marfori et al., 2015).

The barks of L.domesticum cv duku was reported to contain onocerane triterpenoid, lansionic acid, onoceratriene, lansiolic acid, lansiolic acid A, 21 $\alpha$-hidroxyonocera-8(26),14diene-3-one, dan $\alpha$-onoceradiendione. These compounds showed antifeedant activity against Sitophilus oryzae (Tanaka et al., 2002). Previous phytochemical studies on the bark of L. domesticum cv kokossan have revealed the presence of 8,14-secogammacera-7,14-diene3,21-dione; 8,14-seco-gammacera-7-ene-14hidroxy-3,21-dione and 8,14-secogammacera7,14(27)-diene-3,21-dione (Mayanti et al., 2011). Cycloartane triterpenoids, 3-oxo-24cycloarten-21-oic acid and 9, 19-cyclolanost24-en-3-one, 21,23 epoxy-21,22-dihydroxy $(21 R, 22 S, 23 S)$ were reported as components of the leaves of L.domesticum cv duku and cv kokossan (Mayanti et al., 2015). In this paper, the antibacterial activity of compounds $\mathbf{1 - 3}$ which will be discussed.

\section{MATERIALS AND METHODS}

\section{Equipments}

Optical rotations were recorded on a Perkin-Elmer 341 polarimeter. The UV spectra were obtained on a UV Ultraspec 3000 Pro spectrophotometer. The IR spectra were recorded on a Perkin-Elmer 1760X FT-IR in $\mathrm{KBr}$. The mass spectra were recorded with a Mariner Biospectro. -Finnigan instrument. ${ }^{1} \mathrm{H}-$ and ${ }^{13} \mathrm{C}$-NMR spectra were obtained with a JEOL JNM A-500 spectrometer using TMS as internal standard. TLC plates were precoated with silica gel GF254 (Merck, $0.25 \mathrm{~mm}$ ) and detection was achieved by spraying with $10 \%$ $\mathrm{H}_{2} \mathrm{SO}_{4}$ in ethanol, followed by heating.

\section{Plant Materials}

The bark of L. domesticum $\mathrm{cv}$ kokossan were collected in Cililin District, Bandung, West Java Province, Indonesia, in March 2006. The plant was identified by the Laboratory of Plant Taxonomy, Department of Biology, Padjadjaran University, Indonesia. A voucher specimen (No.10184) was deposited at the herbarium of the Padjadjaran University. Samples of the leaves L. domesticum cv kokossan were collected in July 2013 from Tasikmalaya, West Java Province, Indonesia. The plant was identified by the staff at Department of Biology, Padjadjaran University. A voucher specimen (No. 10188) was deposited at the herbarium of the Padjadjaran University.

\section{Plant extraction}

The dried bark of $L$. domesticum $\mathrm{cv}$ kokossan $(3 \mathrm{~kg})$ was extracted with $15 \mathrm{~L}$ methanol at room temperature for 3 days. The methanol extract $(250 \mathrm{~g})$ was partitioned with $n$-hexane $(3 \mathrm{~L})$ and ethyl acetate $(3 \mathrm{~L})$ to give an $n$-hexane soluble fraction $(70 \mathrm{~g})$ and an ethyl acetate soluble fraction ( $40 \mathrm{~g}$ ). The ethyl acetate fraction was subjected to vacuum column chromatography on silica gel 60 by using a step gradient of $n$-hexane/ethyl acetate. The fraction eluted with $n$-hexane:ethyl acetate (80:20) was further separated by column chromatography on silica gel using $n$ hexane:ethyl acetate (95:5) to yield an active fraction $(1.5 \mathrm{~g})$. The active fraction was further chromatographed on silica gel using $n$-hexane/ acetone (90:10) to give $\mathbf{1}(10 \mathrm{mg})$ and $\mathbf{2}$ (50 $\mathrm{mg})$.

The dried leaves $(2.0 \mathrm{~kg})$ were extracted with methanol $(5 \mathrm{~L})$ at room temperature for 3 days. After removal of the solvent under reduced pressure, the viscous concentrate of $\mathrm{MeOH}$ extract (49.7 g) was first suspended in $\mathrm{H}_{2} \mathrm{O}$ and then partitioned with $n$ hexane and EtOAc, successively. $16.7 \mathrm{~g}$ of the crude ethyl acetate was subjected to column chromatography over silica gel using a gradient of $n$-hexane, EtOAc, and $\mathrm{MeOH}$ (10:0-0:10) to give 22 fractions (A1-A22). Fraction A6 (1.9 g) [ $n$-hexane:EtoAc/6:4 ] was subjected to silica gel column chromatography, eluted with the mixtures of $n$-hexane $/ \mathrm{CHCl}_{3}$ (10:0-8:2) as eluting solvents to give17 fractions (B01-B15). The Fraction of B06 to B07 were combined and to give $3(30.0 \mathrm{mg})$ after crystallized using acetone solvent.

\section{Antibacterial Activity}

The compounds $\mathbf{1}$ and $\mathbf{2}$ were tested against gram positive and gram negative species, Escherichia coli and Bacillus cereus. 
Antibacterial activity test was performed in vitro using paper discs with a diameter of 6 $\mathrm{mm}$. Chloroform is used as a control.

\section{Prepararation of agar medium}

A total of $7.2 \mathrm{~g}$ of nutrient broth $(2 \mathrm{~g}$ sodium chloride $0.85 \% ; 1.2 \mathrm{~g}$ of beef extract and peptone $4 \mathrm{~g}$ ) was suspended in $400 \mathrm{~mL}$ of distilled water. $12 \mathrm{~g}$ of agar was then added and heated until dissolved. Then it was sterilized in an autoclave for 15 minutes at 121 ${ }^{\circ} \mathrm{C}$. Provision bacterial test was done on an agar medium (an inclined surface) and incubated at $37{ }^{\circ} \mathrm{C}$ for $18-24$ hours.

\section{Determination of antibacterial activity}

Samples were dissolved in chloroform, and a paper disk was dipped into the solution and sterilized using ultraviolet light for 24 hours. Paper discs containing the sample was placed on the surface of the agar and incubated for $18-24$ hours at $37{ }^{\circ} \mathrm{C}$. After passing the incubation period, the diameter of inhibition zone formed in the form of clear zone, measured as a parameter to determine the antibacterial activity.

The compound $\mathbf{3}$ was tested against gram positive and gram negative species, Escherichia Coli ATCC25922 and Enterococcus feacalis ATCC 29212 respectively. $0.5 \mathrm{~mL}$ each of the culture (McFarland) was pipetted into $5 \mathrm{~mL}(1: 10)$ of saline solution. $0.5 \mathrm{~mL}$ of the mixtures were spreaded onto Mueller Hinton agar plates (Difco Laboratories, Detroit, $\mathrm{mL}, \mathrm{USA}$ ). The plates were incubated overnight at $37^{\circ} \mathrm{C}$ in an incubator.The plates were observed for microbials growth. Isolates with concentrations of $10.000,5.000$, and $1000 \mu \mathrm{g} / \mathrm{mL}$ were added to a $2 \mathrm{~mm}$ diameter area of the paper dishes. The plates were incubated for $24 \mathrm{~h}$ at $37^{\circ} \mathrm{C}$. The inhibition zone was observed and the diameter was measured. Each experiment consisted of two replicates and was repeated twice.

\section{RESULTS AND DISCUSSION}

Isolation and purification of compounds 1-3 have been reported previously (Mayanti et al., 2011; 2015). The analysis of spectroscopic data indicate that compound 1 was 8,14-seco-gammacera-7,14-dien-3,21dione, compound 2 is 8,14 -secogammacera-7- en-14-hydroxy-3,21-dione (Mayanti et al., 2011) and compound 3 was determined as 9, 19-cyclolanost-24-en-3-one, 21,23 epoxy21,22-dihydroxy $(21 R, 22 S, 23 S)$ (Mayanti et al., 2015).<smiles>CC1=CCC2C(CCC3C(C)=CCC4[C@@H](C)C(=O)CC[C@@H]34)[C@]2(C)CCC1=O</smiles><smiles>CC1=CC[C@H]2C(C)(C)C(=O)CC[C@]2(C)C1CCC1C2CCC(=O)C(C)(C)C2CCC1(C)O</smiles><smiles>CC(C)=CC1OC(O)[C@H](C2CC[C@H]3C4CCC5C(C)(C)C(=O)CC[C@]5(C)C4CC[C@]23C)[C@H]1O</smiles>

Antibacterial effect of the methanol extracts, $n$ hexane and ethyl acetate extracts of $L$. domesticum barks were investigated against $E$. coli and B. cereus (Table 1).

The antibacterial activities of the extracts increased linearly with increase in concentration of extracts (\%). The ethyl acetate extract shows the greatest inhibition zone against E.coli at concentration of $1.0 \%$. Separation and purification of the ethyl acetate fraction kokosan bark produced compounds $\mathbf{1}$ and 2. Antibacterial activities of $\mathbf{1}$ and $\mathbf{2}$ were evaluated against E. coli and B. cereus (Table 2).

All of the extract were evaluated for their antibacterials activities toward E. coli as a negative-gram and E. feacalis as a positivegram. EtOAc extract showed lowest activity that can be seen on the zone inhibition, whereas $n$-hexane and $\mathrm{H}_{2} \mathrm{O}$ extracts were in active. The ethyl acetate fraction of kokosan leaves were subjected to silica gel column chromatography to give compound 3 (9, 19- 
cyclolanost-24-en-3-one, 21,23 epoxy-21,22dihydroxy $(21 R, 22 S, 23 S)$. Compound 3 was evaluated for antibacterial activities against the E. coli as a gram-negative and E. feacalis as a gram-positive. After incubated for $24 \mathrm{~h}$ at $37^{\circ} \mathrm{C}$, compound $\mathbf{3}$ showed the inhibition zone values of $3.67 \mathrm{~mm}, 3.17 \mathrm{~mm}, 2.32 \mathrm{~mm}$ for $E$. coli, whereas for E. feacalis it was inactive. Activity of compound $\mathbf{3}$ was influenced by hydroxyl group, whereas aliphatic ring substituents of 9,19-cyclolanost-24-en-3-one, 21,23 epoxy-21,22-dihydroxy $(21 R, 22 S, 23 S)$ slightly decreased the antibacterial activity (Veldhuizen et al., 2006).

\section{CONCLUSION}

Compound $\mathbf{1}$ and $\mathbf{2}$ had low activities against Escherichia coli and were inactive against Bacillus cereus. Compound $\mathbf{3}$ had low activity against Escherichia coli and was inactive against Enterococcus feacalis.

\section{ACKNOWLEDGEMENT}

This study was financially supported by Directorate General of Higher Educational (Hibah Bersaing, 2005-06 and Hibah Kompetensi, 2016).

\section{REFERENCES}

Loekitowati, H., Poedji \& Hermansyah, 2000, Studi Pemanfaatan Biji Duku (Lansium domesticum Jack) Untuk Obat Diare Secara In vitro, Jurnal Penelitian Sains, 7: 41-48.
Marfori, E.C., Kajiyama, S.I., Fukusaki, E. \& Kobayashi A, 2015, Lansioside D, A New Triterpenoid Glycoside Antibiotic from The Fruit Peel of Lansium domesticum Correa, J. Pharm. Phytochem., 3(5): 140-143.

Mayanti, T., Tjokronegoro, R., Supratman, R., Mukhtar, M.R., Awang, K., and Hadi, H.A., 2011, Antifeedant Triterpenoids from the Seeds and Bark of Lansium domesticum cv Kokossan (Meliaceae), Molecules, 16: 2785-95, doi: 10.3390/ molecules 16042785 .

Mayanti, T., Sianturi, J., Harneti, D., Darwati, Supratman, U., Rosli, M.M., and Fun, H.K., 2015, 9,19-Cyclolanost-24-en-3one, 21,23epoxy-21,22-dihydroxy $(21 R$, $22 S, 23 S$ ) from the Leaves of Lansium domesticum Corr cv Kokossan, Molbank: M880; doi: 10.3390/M880.

Ragasa, C.Y., Labrador, P. And Rideout, J.A, 2006, Antimicrobial Terpenoids from Lansium domesticum, The Philippine Agricultural Scientist, 89(1): 101-106.

Tanaka, T.; Ishibashi, M.; Fujimoto, H.; Okuyama, E.; Koyano, T.; Kowiyhayakorn, T.; Hayashi, M.; Komiyama, K, New Onoceranoid Constituents from Lansium domesticum, J. Nat. Prod, 2002, 65: 1709-1711.

Veldhuizen, E.J.A., Bokhoven, J.L.M.T., Zweijtzer, C., Burt, S.A., Haagsman, H.P., 2006, Structural Requirements for the Antimicrobial activity of Carvacrol, J.Agri. Food. Chem., 54: 1874-1879.

Tabel 1. Antibacterial Activity of methanol extracts, $n$-hexane extracts and ethyl acetate extracts of L. domesticum barks against E. coli and B. cereus.

\begin{tabular}{cccc}
\hline Extracts & $\begin{array}{c}\text { Concentration } \\
(\mathrm{ppm})\end{array}$ & \multicolumn{2}{c}{$\begin{array}{c}\text { Antibacterial activity } \\
\text { Zone of inhibition in mm }\end{array}$} \\
\cline { 3 - 4 } & & E. coli & B.cereus \\
\hline Methanol & 1000 & 10.0 & 8.0 \\
& 5000 & 13.5 & 9.5 \\
$n$-hexane & 10000 & $-*$ & 10.5 \\
& 1000 & $-*$ & $-*$ \\
Ethyl acetate & 5000 & $-*$ & $-*$ \\
& 10000 & $-*$ & $-*$ \\
& 1000 & 9.0 & 11.0 \\
& 5000 & 10.5 & 10.5 \\
\hline
\end{tabular}

*no inhibition zone 
JURNAL KIMIA 12 (1), JANUARI 2018: 54 -58

Tabel 2. Antibacterial activity of compound 1 and 2 of L. domesticum barks against E.coli and B. cereus

\begin{tabular}{cccc}
\hline Extracts & $\begin{array}{c}\text { Concentration } \\
(\mathrm{ppm})\end{array}$ & \multicolumn{2}{c}{$\begin{array}{c}\text { Antibacterial activity } \\
\text { Zone of inhibition in mm }\end{array}$} \\
\cline { 3 - 4 } & & E. coli & B.cereus \\
\hline 1 & 500 & 7.5 & $-*$ \\
2 & 000 & 8.0 & $-*$ \\
Vancomycin & 500 & 8.0 & $-*$ \\
chloramphenicol & & 17.5 & 13.0 \\
sulphonamide & & 18.5 & 17.0 \\
\hline
\end{tabular}

*no inhibition zone 